\title{
Examination of Film Thickness Dependence on Acoustic Impedance of Gold and Chromium Thin Films by Scanning Acoustic Microscopy
}

\author{
Altın ve Krom İnce Filmlerin Akustik Empedansının Film Kalınlı̆̆ına Bağlılığının Taramalı \\ Akustik Mikroskopisi ile Araştırılması
}

\section{Bukem TANOREN ${ }^{1}$}

\author{
${ }^{1}$ Acibadem University, Department of Natural Sciences, 34752, Istanbul, Turkey
}

\begin{abstract}
Thickness induced changes in acoustic impedance of gold ( $\mathrm{Au}$ ) and chromium $(\mathrm{Cr})$ thin films are studied with scanning acoustic microscopy (SAM). Thin films are produced by thermal evaporation technique on BK7 glass substrates with varying thicknesses between $40 \mathrm{~nm}$ to $200 \mathrm{~nm}$. In acoustic impedance (AI) mode, the microscope generates two-dimensional acoustic impedance maps of the thin films and micrometer resolution helps determining the surface defects on these films. On the other hand, acoustic impedance value is found to increase as thickness increases for both $\mathrm{Au}$ and $\mathrm{Cr}$ thin films indicating increased elasticity, therefore, hardness. The acoustic impedance of $\mathrm{Cr}$ thin films were found as $1.901 \pm 0.050$ MRayl for $40 \mathrm{~nm}, 1.905$ \pm 0.045 MRayl for $80 \mathrm{~nm}, 1.943 \pm 0.049$ MRayl for $120 \mathrm{~nm}, 1.964 \pm 0.049$ MRayl for $160 \mathrm{~nm}$ and $1.987 \pm 0.052$ MRayl for $200 \mathrm{~nm}$. The acoustic impedance of Au thin films were found as $1.725 \pm 0.026$ MRayl for $80 \mathrm{~nm}$ and $1.954 \pm 0.047$ MRayl for $200 \mathrm{~nm}$. This success achieved by SAM, demonstrates its potential in monitoring thin film surfaces even with very small thicknesses.

Keywords: Acoustic microscopy, gold thin films, chromium thin films

$\ddot{\mathbf{O} z}$

Altın $(\mathrm{Au})$ ve krom $(\mathrm{Cr})$ ince filmlerin akustik empedansındaki kalınlığa bağlı değişiklikler, taramalı akustik mikroskobu (TAM) ile incelenmiştir. İnce filmler, $40 \mathrm{~nm}$ ile $200 \mathrm{~nm}$ arasında değişen kalınlıklarda BK7 cam alt tabakalar üzerinde termal buharlaştırma tekniği ile üretilir. Akustik empedans (AE) modunda, mikroskop ince filmlerin iki boyutlu akustik empedans haritalarını oluşturur ve mikrometre çözünürlüğü bu filmlerdeki yüzey kusurlarının belirlenmesine yardımcı olur. Öte yandan, hem $\mathrm{Au}$ hem de $\mathrm{Cr}$ ince filmler için artan elastiklik yani sertlik nedeniyle, kalınlık arttıkça akustik empedans değerinin arttığı bulunmuştur. Cr ince filmlerin akustik empedans $40 \mathrm{~nm}$ için $1.901 \pm 0.050$ MRayl, $80 \mathrm{~nm}$ için $1.905 \pm 0.045$ MRayl, $120 \mathrm{~nm}$ için $1.943 \pm 0.049$ MRayl, $160 \mathrm{~nm}$ için $1.964 \pm 0.049$ MRayl ve $200 \mathrm{~nm}$ için $1.987 \pm 0.052$ MRayl olarak bulundu. Au ince filmlerin akustik empedansı $80 \mathrm{~nm}$ için $1.725 \pm 0.026$ MRayl ve $200 \mathrm{~nm}$ için $1.954 \pm 0.047$ MRayl olarak bulundu. SAM ile elde edilen bu başarı, çok küçük kalınlıklarda bile ince film yüzeylerinin izlenmesindeki potansiyelini göstermektedir.
\end{abstract}

Anahtar Kelimeler: Akustik mikroskopisi, altın ince filmler, krom ince filmler

\section{INTRODUCTION}

Nondestructive thin film characterization methods are required for sub-micrometer dimensions. Particularly, mechanical characterization is fundamental for thin films designed for devices in which they may be subjected to stresses and damaged. X-ray diffraction (XRD) technique $[1,2]$ can determine the crystallographic structure of a material, while scanning electron microscopy (SEM) [2] and atomic force microscopy (AFM) or atomic force acoustic microscopy (AFAM) [3, 4] obtain two-dimensional structural information in nanometer scale. An alternative imaging modality called scanning acoustic microscopy (SAM) can be used for thin film surface characterizations [5-7].

Thin films are used in many applications such as optoelectronic and photovoltaic systems [8, 9], magnetic storage systems [10] or chemical biosensors [11]. Their electrical or magnetic properties change according to their preparation conditions [12], thickness of the films [5], substrates on which they are grown [3] and also aging [13]. Chromium $(\mathrm{Cr})$, being the first metal investigated as a thin film resistor with no superconductivity even under pressure, and gold $\mathrm{Au}$ ), being a unique material with high chemical stability and electrical conductivity especially in porous form [14], gain attention from scientists and therefore, highly examined.

In this study, $\mathrm{Cr}$ and $\mathrm{Au}$ thin films with varying thicknesses on BK7 substrates were investigated by SAM and AFM. Thin films were grown by chemical vapor deposition on same type of glass substrates to exclude the 
influence of substrate and concentrate only on thickness of thin film by keeping all parameters the same, except the time of deposition. AFM measurements are done for specifying the morphology and thickness of thin film surfaces. SAM system obtains 2-dimensional maps of $4.8 \mathrm{~mm} \times 4.8 \mathrm{~mm}$ area within couple of minutes and without a necessity of a special sample preparation. The acoustic impedance value was found to increase as thickness was increased, denoting an increase in elasticity, in other words, hardness. This achievement is an indication that SAM can be used widely as a mechanical characterization tool for thin film surfaces in the future.

\section{MATERIALS AND METHODS}

\subsection{Thin films}

Thin films of Gold ( $\mathrm{Au}$ ) and chromium $(\mathrm{Cr})$ were prepared by thermal evaporation, using Edwards Coating System E306A. BK7 glass substrates were used for thin film preparation and before deposition, they were cleaned first with a chemical detergent, followed by acetone and methanol in an ultrasonic vibrator. The clean substrates were placed on a holder, which was about $10 \mathrm{~cm}$ above the source, inside Edwards Coating System, and the evaporation source was placed inside a tungsten boat below the holder, as shown in Figure 1. The raw materials of $\mathrm{Au}$ and $\mathrm{Cr}$ were heated by resistive heating. During thermal evaporation, the chamber pressure was kept around $7 \times 10^{-6}$ mbar. The thickness of the films was altered between $40 \mathrm{~nm}$ to $200 \mathrm{~nm}$ by just changing the evaporation time of the materials, while keeping other parameters exactly the same.

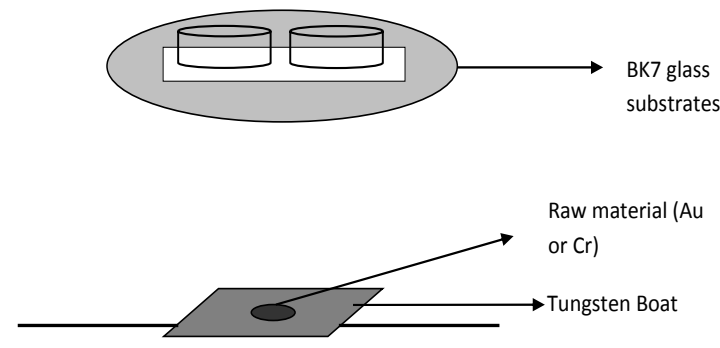

Figure 1. Layout within the evaporation unit.

\subsection{Atomic force microscopy}

Atomic force microscopy (AFM) measurements were done with Universal Scanning Probe Microscope (USPM) developed by Ambios-Quesant. AFM is performed in tapping mode to avoid surface damage. It has a 250x video microscope, easy change cantilever, a $40 \mu \mathrm{m} \times 40 \mu \mathrm{m} \times 4 \mu \mathrm{m}$ scan tube assembly and Acoustic/Vibration Isolation Chamber (AVIC).

\subsection{SAM}

In Figure 2, SAM setup is shown. Scanning acoustic microscope (AMS-50SI) was developed by Honda Electronics (Toyohashi, Japan). Acoustic impedance
(AI) mode of SAM is used. Transducer used in SAM has $80 \mathrm{MHz}$ center frequency. Transducer generates the ultrasound signals and also collects the reflected signals. The coupling medium between the quartz lens and the BK7 substrate is distilled water. 2-dimensional maps are obtained by scanning the transducer mounted on the X-Y stage. Consequently, acoustic intensity and impedance maps with 300 x 300 sampling points are obtained, simultaneously.

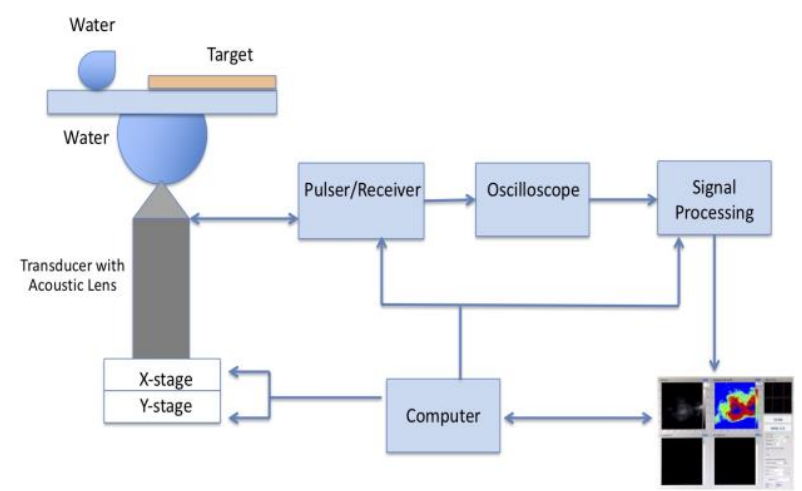

Figure 2. SAM setup in AI mode. Acoustic impedance of the target is obtained by analyzing the signals reflected from water and the target (thin film surface).

The reference material is distilled water. Transducer generates a constant signal $\mathrm{S}_{0}[15]$. The target reflects this generated ultrasound signal as

$S_{\text {target }}=\frac{Z_{\text {target }}-Z_{\text {sub }}}{Z_{\text {target }}+Z_{\text {sub }}} S_{0}$

Thin film's acoustic impedance is $Z_{\text {target }}$ and the substrate's impedance is $Z_{\text {sub. }}$. The reference (water) with acoustic impedance $Z_{\text {ref }}$ reflects the signal as

$S_{\text {ref }}=\frac{Z_{r e f}-Z_{\text {sub }}}{Z_{\text {ref }}+Z_{\text {sub }}} S_{0}$

Finally, the thin film's acoustic impedance is written as

$Z_{\text {target }}=\frac{1+\frac{S_{\text {target }}}{S_{0}}}{1-\frac{S_{\text {target }}}{S_{0}}} Z_{\text {sub }}$

\section{III.FINDINGS AND DISCUSSION}

Figure 3 shows the representative three-dimensional AFM image of a thin film surface on a BK7 glass substrate, which was prepared as shown in Figure 1. As can be seen in Figure 3, the thickness of $\mathrm{Cr}$ thin film is around $40 \mathrm{~nm}$ for this sample. The inhomogeneities are also observed but only at the edges of the thin film surfaces. The other thin films with different thicknesses are obtained by only changing evaporation time for the raw source within tungsten boat, keeping all other parameters exactly the same. Chromium and gold thin film surfaces with varying thickness values can also be seen in real photographs in Figures 4 and 5, respectively. 

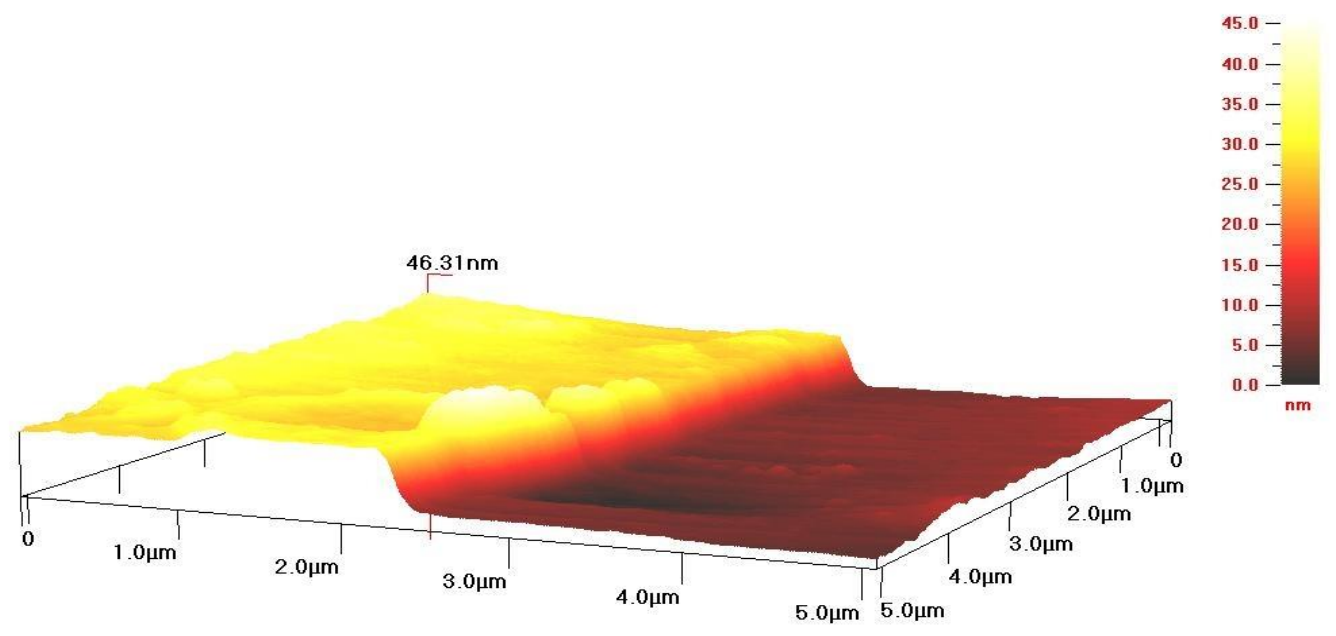

Figure 3. Three-dimensional AFM image of the $\mathrm{Cr}$ thin film of thickness of $40 \mathrm{~nm}$.

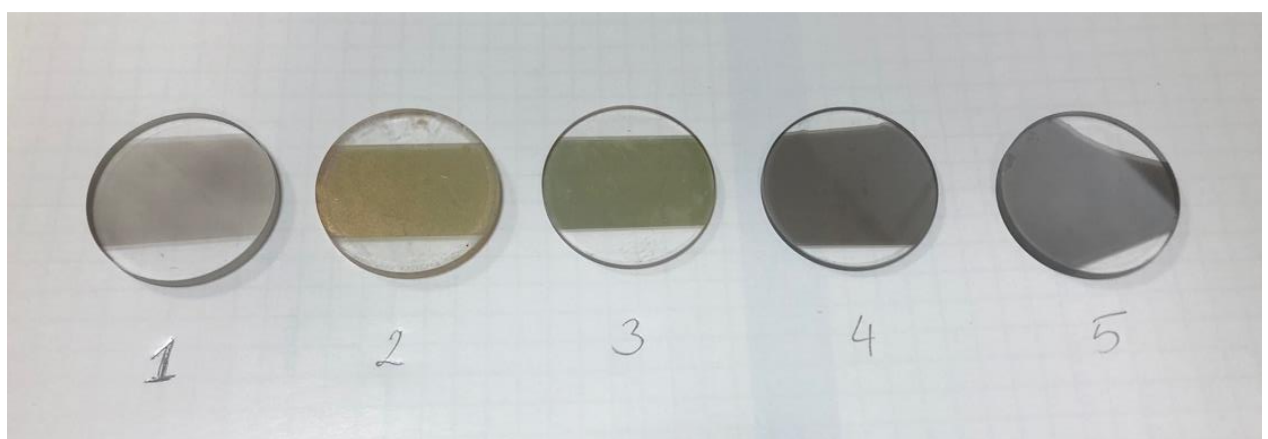

Figure 4. Real photograph of the chromium thin films of thickness of 1) $40 \mathrm{~nm}, 2) 80 \mathrm{~nm}, 3) 120 \mathrm{~nm}$, 4) $160 \mathrm{~nm}$ and 5) $200 \mathrm{~nm}$.

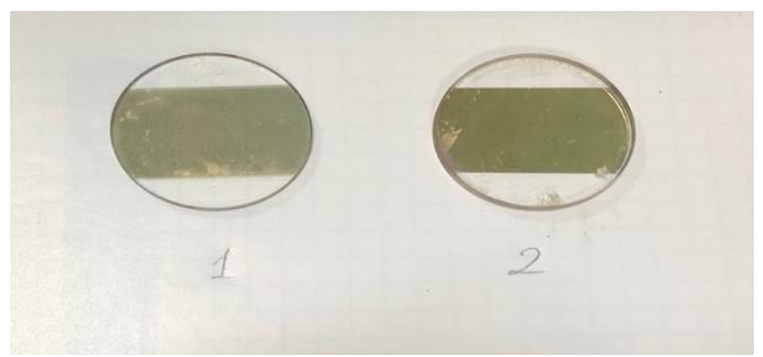

Figure 5. Real photograph of the gold thin films of thickness of 1) $80 \mathrm{~nm}$ and 2) $200 \mathrm{~nm}$.

Table 1 summarizes SAM results of Cr thin films. 2dimensional scans were performed on areas of $4.8 \mathrm{~mm}$ x $4.8 \mathrm{~mm}$ with $300 \times 300$ points. The acoustic impedance value was found to increase as thickness was increased as a result of increased hardness and elasticity. Table 2 summarizes SAM results for Au thin films but for only 2 different thickness values, starting from $80 \mathrm{~nm}$, since there was no pronounced acoustic impedance difference between $40 \mathrm{~nm}$-thick and $80 \mathrm{~nm}$ thick films. Similarly, as the film thickness is increased the surface became more robust and therefore the acoustic impedance increased. Figure 6 shows thickness dependence on acoustic impedance of thin films. In this figure, it is observed that Au films become more stable with higher elasticity as thickness is increased, on the other hand, thickness dependence is more modest for $\mathrm{Cr}$ thin films, since $\mathrm{Cr}$ is better adsorbed on BK7 surfaces even with a very small thickness value. 
Table 1. Thickness dependence of acoustic impedance values of $\mathrm{Cr}$ thin films.

\begin{tabular}{|c|c|}
\hline $\begin{array}{c}\text { Thickness of Thin } \\
\text { Films (nm) }\end{array}$ & $\begin{array}{c}\text { Acoustic Impedance } \\
\text { (MRayl) }\end{array}$ \\
\hline 40 & $1.901 \pm 0.050$ \\
\hline 80 & $1.905 \pm 0.045$ \\
\hline 120 & $1.943 \pm 0.049$ \\
\hline 160 & $1.964 \pm 0.049$ \\
\hline 200 & $1.987 \pm 0.052$ \\
\hline
\end{tabular}

Table 2. Thickness dependence of acoustic impedance values of $\mathrm{Au}$ thin films.

\begin{tabular}{|c|c|}
\hline $\begin{array}{c}\text { Thickness of Thin } \\
\text { Films (nm) }\end{array}$ & $\begin{array}{c}\text { Acoustic Impedance } \\
\text { (MRayl) }\end{array}$ \\
\hline 80 & $1.725 \pm 0.026$ \\
\hline 200 & $1.954 \pm 0.047$ \\
\hline
\end{tabular}

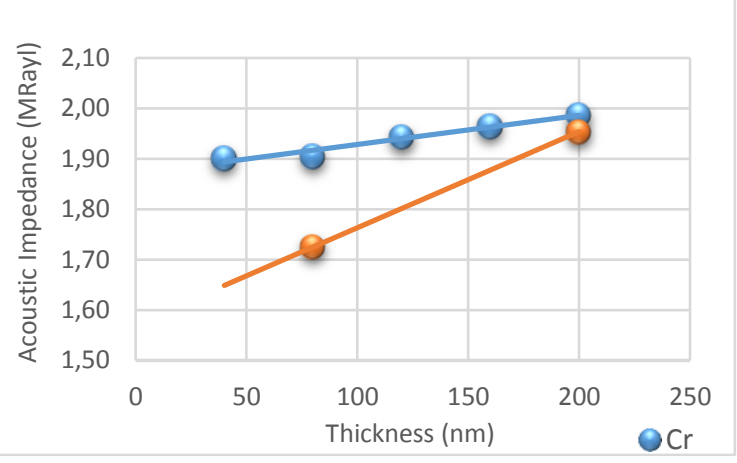

Figure 6. Thickness dependence on acoustic impedance of thin films.

Figure 7, Figure 8 and Figure 9 show acoustic impedance maps of $40 \mathrm{~nm}$-thick, $120 \mathrm{~nm}$-thick and 200nm-thick Cr films, respectively. SAM obtains 2dimensional acoustic impedance maps by sending and collecting the reflected ultrasound signals by the same transducer of $80 \mathrm{MHz}$. As can be observed in Figures 7-9, mean acoustic impedance value increases as thickness is increased more rapidly around $120 \mathrm{~nm}$.

Figure 10 shows acoustic impedance map of $80 \mathrm{~nm}$ thick Au film, while Figure 11 shows acoustic impedance map of $200 \mathrm{~nm}$-thick Au film. The increase in acoustic impedance is obvious when these figures are considered. The inhomogeneous parts probably belong to voids on film surfaces or dirt on substrates.

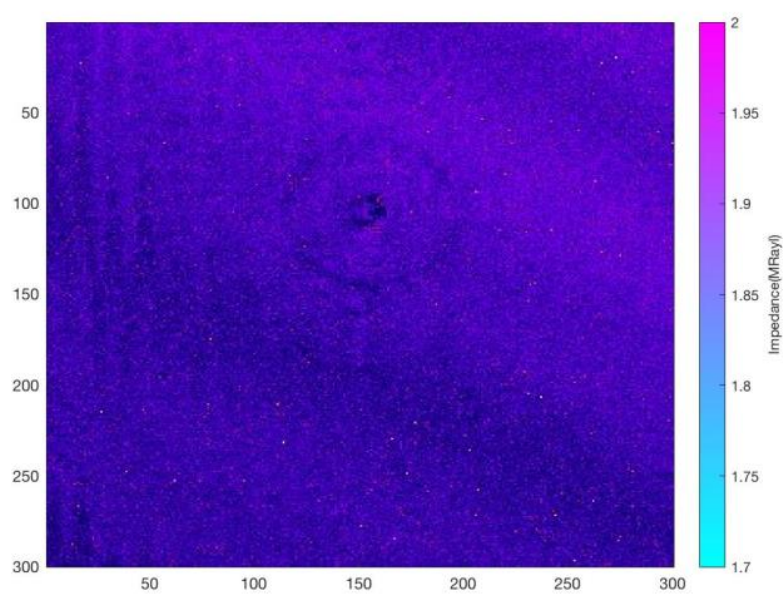

Figure 7. SAM image of the chromium thin film of thickness of $40 \mathrm{~nm}$. Scanning area is $4.8 \mathrm{~mm} \times 4.8$ $\mathrm{mm}$.

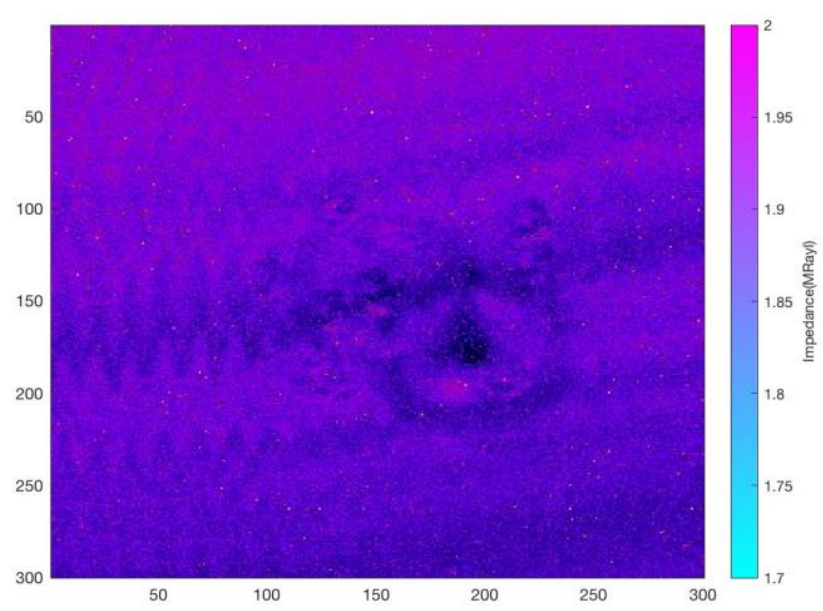

Figure 8. SAM image of the chromium thin film of thickness of $120 \mathrm{~nm}$. Scanning area is $4.8 \mathrm{~mm} \times 4.8$ $\mathrm{mm}$.

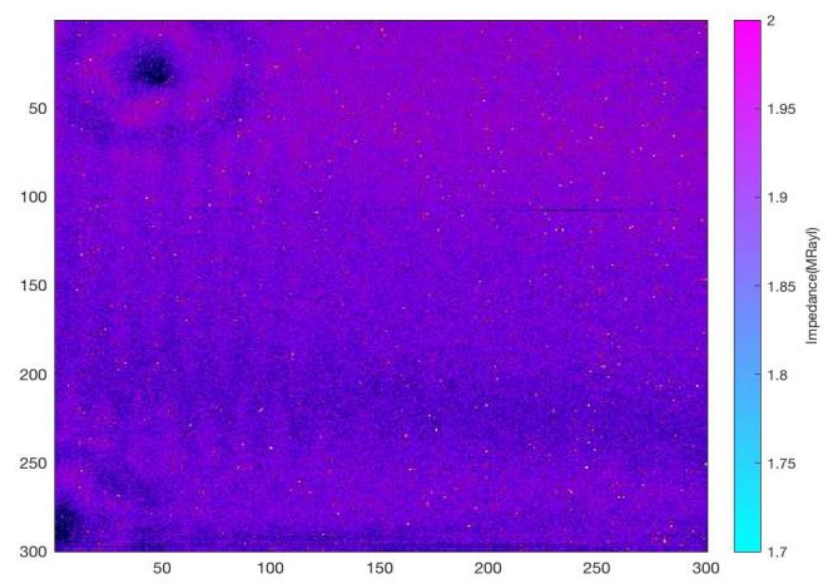

Figure 9. SAM image of the chromium thin film of thickness of $200 \mathrm{~nm}$. Scanning area is $4.8 \mathrm{~mm} \times 4.8$ $\mathrm{mm}$ 


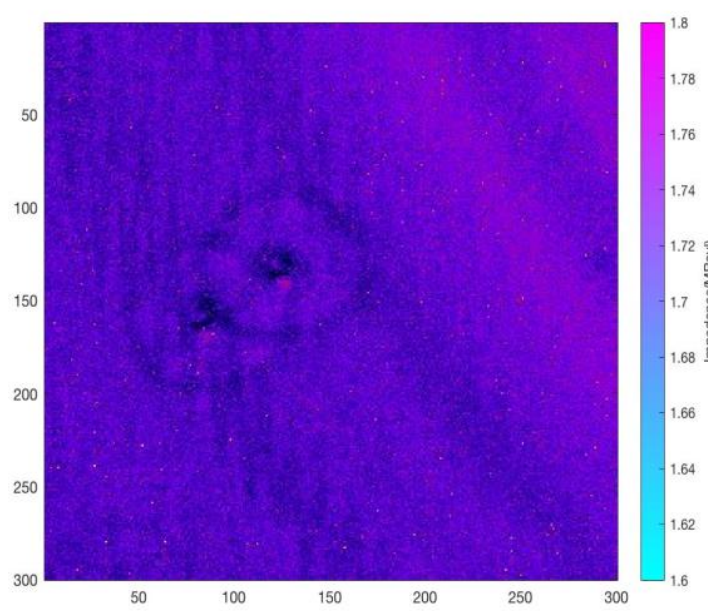

Figure 10. SAM image of the gold thin film of thickness of $80 \mathrm{~nm}$. Scanning area is $4.8 \mathrm{~mm} \times 4.8$ $\mathrm{mm}$.

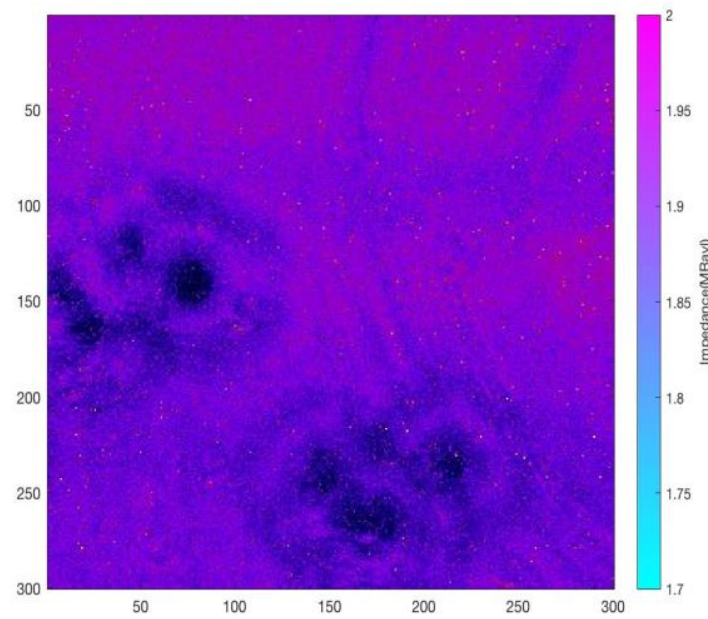

Figure 11. SAM image of the gold thin film of thickness of $200 \mathrm{~nm}$. Scanning area is $4.8 \mathrm{~mm} \mathrm{x} 4.8$ $\mathrm{mm}$.

\section{CONCLUSION AND EVALUATIONS}

In this study, SAM monitored thin films of $\mathrm{Cr}$ and $\mathrm{Au}$ grown on BK7 substrates. The films consist of either $\mathrm{Cr}$ or Au. Surface morphology of films were also assessed with AFM measurements. Figure 3 illustrates one representative three-dimensional AFM image of 40 nm-thick $\mathrm{Cr}$ thin film surface on a BK7 glass substrate. As can be seen in Figure 3, thin film surfaces are almost smooth with inhomogeneities at the edges, therefore, SAM measurements were performed on homogenous parts of all thin film surfaces. As thickness changed the surface morphology of the deposited films also changed, which can be observed in real photographs of film surfaces (Figure 4 and Figure 5). As can be seen in these figures, the color of the surfaces varies with thickness, indicating varying light wavelength the surface absorbs. In other words, by adjusting thin film thickness, optical properties can be tuned and this flexibility has made thin films useful as optoelectronic materials in many applications $[16,17]$.

Figure 6 shows the thickness dependence on acoustic impedance of thin films. For Au films, increase in acoustic impedance value is prominent, indicating a more pronounced elasticity with thickness increase. This may be a result of the difference in adsorption properties of $\mathrm{Au}$ and $\mathrm{Cr}$ films on BK7 substrates, since $\mathrm{Cr}$ layers are being used to increase adhesion of $\mathrm{Au}$ layers on polymer surfaces [18].

Two-dimensional SAM images were constructed by reflecting ultrasound signals from both surfaces of reference and thin film. In Figures 7-11, few defects with different elasticity were observed on the surfaces by different acoustic impedance values. Twodimensional scanning with SAM provided information about the morphology and mechanical behaviour of thin film surfaces with micrometer resolution. Mean value of acoustic impedance of thin film surface was calculated over an area of $4.8 \mathrm{~mm}$ x $4.8 \mathrm{~mm}$ for each sample examined and shown in Table 1 and 2 for $\mathrm{Cr}$ and $\mathrm{Au}$, respectively. Standard deviations, which are probably due to voids on film surfaces or dirt on substrates, were less than $3 \%$.

The increase in acoustic impedance as thickness is increased describes the increase in hardness of thin film surfaces. $200 \mathrm{~nm}$-thick $\mathrm{Cr}$ and $\mathrm{Au}$ surfaces obtain the highest acoustic impedance values due to increased elasticity, while they also become more robust physically, which supports SAM results. Success of SAM in monitoring the thin film surfaces is of great importance, since it is quick, does not require a special preparation technique and has a micro-meter lateral resolution [19-21]. Besides, the resolution may be further increased with a higher frequency transducer $[22,23]$. However, with $80 \mathrm{MHz}$ transducer SAM has a resolution of $17 \mu \mathrm{m}$ with a moderate price.

In this study, SAM characterized $\mathrm{Cr}$ and $\mathrm{Au}$ thin film surfaces of varying thicknesses between $40 \mathrm{~nm}$ to 200 nm. Acoustic impedance maps analyzed surfaces twodimensionally and average acoustic impedance values of the surfaces were calculated in couple of minutes. Immediate observation capacity of SAM with a moderate price makes this modality a very good candidate for surface analyses. SAM on probe is definitely a consideration for a future study and will be useful in many other applications in addition to electrooptic applications.

\section{ACKNOWLEDGMENT}

This study was funded by the Ministry of Development of Turkey (grant number 2009K120520). 


\section{REFERENCES}

[1] Coppa, B.J., Fulton, C.C., Kiesel, S.M., Davis, R.F., Pandarinath, C., Burnette, J. E., Nemanich, R.J., \& Smith, D. J. (2005). Structural, microstructural, and electrical properties of gold films and Schottky contacts on remote plasmacleaned, n-type $\mathrm{ZnO}\{0001\}$ surfaces. J. Appl. Phys., 97, 103517.

[2] Catledge, S.A., Vaid, R., Diggins, IV P., Weimer, J.J., Koopman, M., \& Vohra, Y.K. (2011). Improved adhesion of ultra-hard carbon films on cobalt-chromium orthopaedic implant alloy. J. Mater. Sci. :Mater. Med., 22, 307-316.

[3] Udachan, S.L., Ayachit, N.H., \& Udachan, L.A. (2019). Impact of substrates on the electrical properties of thin chromium films. Ing. Univ., 23(2).

[4] Hurley, D.C., Shen, K., Jennett, N.M., \& Turner, J.A. (2003). Atomic force acoustic microscopy methods to determine thin-film elastic properties. J. Appl. Phys., 94, 2347.

[5] Kim, M., Choi, N., Kim, Y., \& Lee, Y. (2018). Characterization of RF sputtered zinc oxide thin films on silicon using scanning acoustic microscopy. J. Electroceram., 40, 79-87.

[6] Guzelcimen, F., Tanoren, B., Cetinkaya, C., Donmez Kaya, M., Efkere, H.I., Ozen, Y., Bingol, D., Sirkeci, M., Kınacı, B., Unlu, M.B., \& Ozçelik, S. (2020). The effect of thickness on surface structure of rf sputtered $\mathrm{TiO} 2$ thin films by XPS, SEM/EDS, AFM and SAM. Vacuum, 182, 109766.

[7] Passeri, D., Bettucci, A., \& Rossi, M. (2010). Acoustics and atomic force microscopy for the mechanical characterization of thin films. Anal. Bioanal. Chem., 396, 2769-2783.

[8] Kumar, K.D.A., Ganesh, V., Shkir, M., AlFaify, S., \& Valanarasu, S. (2018). Effect of different solvents on the key structural, optical and electronic properties of sol-gel dip coated AZO nanostructured thin films for optoelectronic applications. J. Mater. Sci.: Mater. Electron., 29, 887-897.

[9] Tait, J.G., Merckx, T., Li, W., Wong, C., Gehlhaar, R., Cheyns, D., Turbiez, M., \& Heremans, P. (2015). Determination of Solvent Systems for Blade Coating Thin Film Photovoltaics. Adv. Funct. Mater., 25(22), 3393-3398.

[10] Koumoulos, E.P., Markakis, V., Tsikourkitoudi, V.P., Charitidis, C.A., Papadopoulos, N., \& Hristoforou, E. (2015). Tribological characterization of chemical vapor deposited $\mathrm{Co}$ and $\mathrm{Co}_{3} \mathrm{O}_{4}$ thin films for sensing reliability in engineering applications. Tribol. Int., 82(A), 8994.

[11] Arya, S.K., Saha, S., Ramirez-Vick, J.E., Gupta, V., Bhansali, S., \& Singh, S.P. (2012). Recent advances in $\mathrm{ZnO}$ nanostructures and thin films for biosensor applications: Review. Anal. Chim. Acta, 737, 1-2.

[12] Sawabu, M., Ohashi, M., Ohashi, K., Miyagawa, M., Kubota, T., \& Takanashi, K. (2017). The electrical resistivity of epitaxially deposited chromium films. J. Phys.:Conf. Ser., 871, 012002.

[13] Raghavan, R., Harzer, T.P., Djaziri, S., Hieke, S.W., Kirchlechner, C., \& Dehm, G. (2017). Maintaining strength in supersaturated copperchromium thin films annealed at 0.5 of the melting temperature of $\mathrm{Cu}$. J. Mater. Sci., 52, 913-920.

[14] Zhang, R., \& Olin, H. (2014). Porous Gold Films-A Short Review on Recent Progress. Materials, 7, 3834-3854.

[15] Kobayashi, K., Yoshida, S., Saijo, Y., \& Hozumi, N. (2014). Acoustic impedance microscopy for biological tissue characterization. Ultrasonics, 54, 1922-1928.

[16] Dhindsa, N., Walia, J., Pathirane, J.M., Khodadad, Wong, I.W.S., \& Saini, S.S. (2016). Adjustable optical response of amorphous silicon nanowires integrated with thin films. Nanotechnology, 27, 145703.

[17] Kats, M.A., \& Capasso, F. (2014). Ultra-thin optical interference coatings on rough and flexible substrates. Appl. Phys. Lett., 105, 131108.

[18] Putz, B., Schoeppner, R.L., Glushko, O., Bahr, D.F., \& Cordill, M.J. (2015). Improved electromechanical performance of gold films on polyimide without adhesion layers. Scr. Mater., 102, 23-26.

[19] Kobayashi, K., Yoshida, S., Saijo, Y., \& Hozumi, N. (2014). Acoustic impedance microscopy for biological tissue characterization. Ultrasonics, 54, 1922-1928.

[20] Saijo, Y., Miyakawa, T., Sasaki, H., Tanaka, M., \& Nitta, S. (2004). Acoustic properties of aortic aneurysm obtained with scanning acoustic microscopy. Ultrasonics, 42, 695-98.

[21] Miura, K., Nasu, H., \& Yamamoto, S. (2013). Scanning acoustic microscopy for characterization of neoplastic and inflammatory lesions of lymph nodes. Sci. Rep., 3, 1255.

[22] Masugata, H,. Mizushige, K., Senda, S., Kinoshita, A., Lu, X., Sakamoto, H., Sakamoto, S., \& Matsuo, H. (1999). Tissue characterization of myocardial cells by use of high-frequency acoustic microscopy: differential myocyte sound speed and its transmural variation in normal, pressure-overload hypertrophic, and amyloid myocardium. Angiology, 50(10), 837845.

[23] Saijo, Y., Sasaki, H., Sato, M., Nitta, S., \& Tanaka, M. (2000). Visualization of human umbilical vein endothelial cells by acoustic microscopy. Ultrasonics, 38, 396-399. 